\title{
Irrigation Water Demand Model as a Comparative Tool for Assessing Effects of Land Use Changes for Agricultural Crops in Fraser Valley, Canada
}

\author{
Skylar Kylstra* ${ }^{\circledR}$, Autumn D. Watkinson ${ }^{\circledR}$, Lewis Fausak ${ }^{\circledR}$, Leslie M. Lavkulich \\ Faculty of Land and Food Systems, University of British Columbia, Vancouver, Canada \\ Email: ^skylar.kylstra@ubc.ca, autumn.watkinson@ubc.ca, lewis.fausak@ubc.ca,1ml@mail.ubc.ca
}

How to cite this paper: Kylstra, S., Watkinson, A.D., Fausak, L. and Lavkulich, L.M. (2021) Irrigation Water Demand Model as a Comparative Tool for Assessing Effects of Land Use Changes for Agricultural Crops in Fraser Valley, Canada. Agricultural Sciences, 12, 888-906.

https://doi.org/10.4236/as.2021.128057

Received: July 27, 2021

Accepted: August 23, 2021

Published: August 26, 2021

Copyright $\odot 2021$ by author(s) and Scientific Research Publishing Inc. This work is licensed under the Creative Commons Attribution International License (CC BY 4.0).

http://creativecommons.org/licenses/by/4.0/

\section{Open Access}

\begin{abstract}
Available water for human needs and agriculture is a growing global concern. Agriculture uses approximately 70\% of global freshwater, mainly for irrigation. The Lower Fraser Valley (LFV), British Columbia, is one of the most productive agricultural regions in Canada, supporting livestock production and a wide variety of crops. Water scarcity is a growing concern that threatens the long-term productivity, sustainability, and economic viability of the LFV's agriculture. We used the BC Agriculture Water Demand Model as a tool to determine how crop choice, irrigation system, and land-use changes can affect predicted water requirements under these different conditions, which can aid stakeholders to formulate better management decisions. We conducted a comparative assessment of the irrigation water demand of seven major commercial crops, by distinct soil management groups, at nineteen representative sites, that use both sprinkler vs drip irrigation. Drip irrigation was consistently more water-efficient than sprinkler irrigation for all crops. Of the major commercial crops assessed, raspberries were the most efficient in irrigation water demand, while forage and pasture had the highest calculated irrigation water demand. Significant reductions in total irrigation water demand (up to 57\%) can be made by switching irrigation systems and/or crops. This assessment can aid LFV growers in their land-use choices and could contribute to the selection of water management decisions and agricultural policies.
\end{abstract}

\section{Keywords}

Drip Irrigation, Sprinkler Irrigation, Water Management, Water Resources, Agricultural Water Demand Model 


\section{Introduction}

Freshwater resources are becoming increasingly scarce as a result of competing demand for a growing population, competition by industry and energy, as well as the uncertainties caused by climate change [1] [2]. These demands threaten human food and water security and may negatively impact ecosystem integrity [3] [4]. Of the total global freshwater withdrawals, it is estimated that $70 \%$ is used by agriculture, mainly for supplemental irrigation [4] [5]. Combined with growing populations, the expansion and intensification of agriculture are putting additional stress on water resources [5] [6]. Agricultural management decisions are driven by many factors including prior farming experience, economics, and land capability, but in the face of water supply challenges, it is important that land managers also consider current and future water demand and availability. Concerns have been raised that unless water for agriculture is better managed, water resources will not meet agricultural production needs within the next 50 years [7].

While the agriculture sector accounts for the vast majority of the consumptive use of freshwater, agriculture also has the potential for adjustment of water consumption [5]. How agricultural lands are managed influences the longer-term availability of water resources as different crops have different water requirements and different irrigation systems have varying levels of water use efficiency [8]. Adjustments made by farmers in the Fraser Valley of British Columbia will impact the water demand [5]. In the face of water scarcity, it will be important for landowners to consider the selection of crops that is more congruent with the available water. Furthermore, making informed decisions about land use could help mitigate water scarcity issues [5]. To make such decisions, there is a need for reliable tools to help land managers and policymakers to make decisions about land-use-based water considerations.

Globally, groundwater supplies $42 \%$ of irrigation water and comprises $35 \%$ of all water withdrawals [9]. In the LFV, it is estimated that agricultural use comprises about half of all groundwater withdrawals [8] [10]. Surface water and groundwater supply and demand vary among agricultural uses, and as a result, ecosystems and hydrological cycle dynamics are impacted differently by different agricultural uses [10]. For instance, in the LFV, crops such as blueberry and corn need to be irrigated with only groundwater resources due to their intolerance to salinity and the high electrical conductivity of surface water from the Fraser River. However, unmanaged withdrawals of groundwater can result in loss of water in shallow and deep wells, impacting rural residents and farmers who rely on these resources for drinking, irrigation, and livestock. Environmental concerns from consistent over-exploitation of groundwater supplies include lowering of the water table and reduced groundwater input to surface water. In the LFV, out of 53 total aquifers, 5 aquifers are highly vulnerable and 27 are moderately vulnerable to being unable to supply the current water demand [11]. Many of these aquifers provide water for various uses, including drinking water 
and agriculture, and thus withdrawals of irrigation water are often in competition with other uses [12]. To respond to climate change and regional water supply pressures, it is necessary to use a variety of adaptation strategies, including crop selection, adjusting crop planting patterns, and the deployment of water-saving and water-harvesting technologies to help mitigate negative effects [7].

Highly populated regions associated with intensive agriculture are at risk of experiencing water scarcity. In British Columbia, specifically, the cumulative impacts of climate change, water extraction, and population growth are causing documented concern regarding water scarcity, notably during the relatively dry growing season [13] [14]. Climate change will also result in more frequent and sustained droughts, further straining the adaptive capacity for agriculture [15]. Furthermore, many of the watersheds in BC are already fully allocated or will be fully allocated within the next 15 - 20 years [16].

To address the need for sustainable freshwater resources and to help safeguard the water resources needed to sustain BC's 4.7 million hectares of agriculture, the BC Agriculture Water Demand Model was developed. The model was initially developed to measure and predict agricultural water demand in the Okanagan Basin, a relatively arid region (approximately $250 \mathrm{~mm}$ of precipitation per year) [17] and has since been successfully tested in over 25 irrigated areas, including some regions that receive over $2300 \mathrm{~mm}$ of precipitation per year, within the province of British Columbia, Canada [18] [19] [20] [21].

The Agricultural Water Demand Model utilizes regional climate and soil data for local agricultural crop water needs and serves as a comparative tool to assess crop water demand at the farm or field level [22]. Interactive modelling for crop and best management practices has been used previously as an effective aid for farmers and policymakers to examine how changing the agricultural land use of an area affects various environmental receptors [23] [24] [25]. However, the results of the modelling have not been applied to consider changes in water demand due to changes in land use (i.e. selection of crops).

British Columbia's Lower Fraser Valley (LFV) is one of the most intensively farmed regions in Canada and generates the largest annual farm receipts in BC [26]. The region's mild climate and fertile soils make it highly capable of producing a wide variety of crops. However, there is a growing concern in the LFV about balancing local water demand and supply [6]. It has been estimated that by 2030, all total available water will be allocated in the LFV [27]. Furthermore, the region already faces water supply challenges, particularly during the summer growing season. Thus, the challenge of water stress threatens the long-term productivity, sustainability, and economic viability of the LFV's agriculture.

Widespread intensive dairy farms and increasing poultry farms in the LFV require the production of corn, pasture, and forage as feed [26]. Historically, raspberries were dominant in the LFV, but farmers have been increasingly switching to other crops in the past few decades due to increased competition on 
the global raspberry market and the perceived profitability of alternate crops due to government incentives and market volatility [28]. One crop that has grown in popularity is highbush blueberry, the production of which has increased by $33 \%$ in British Columbia between 2005 and 2010, but there has been little concern about changes in water demand by switching crops [29]. Thus, there is a need to address how land-use changes affect water dynamics in the region, which can contribute to informing the best management and policy for agriculture.

\section{Objectives}

The objectives of this paper were to 1) Use the Agricultural Water Demand Model, as a tool to make a comparative assessment of the water requirements for major commercial crops in the LFV and demonstrate how the model can aid agricultural decision-making for effective management of local water resources; 2) Explore the implications for changing water dynamics in the region by a selection of alternate land-use.

\section{Methods}

\subsection{Study Area}

The Lower Fraser Valley, located in southwestern British Columbia, Canada is bounded on the south by the Cascade Mountains, to the north by the BC Coast Mountains, on the east by the Fraser Canyon, and to the west by the Georgia Strait. The LFV is comprised of the Fraser Valley Regional District and the Metro Vancouver Regional District. In this report, the LFV includes the municipalities of Abbotsford, Chilliwack, Delta, Langley, Maple Ridge, Mission, Pitt Meadows, and Surrey (Figure 1). This region is classified as a moderate oceanic climate (Köppen climate classification $\mathrm{Cfb}$ ) with dry summer months, often experiencing moderate drought through July and August. The mean annual temperature is $10.5^{\circ} \mathrm{C}$, with lowest temperatures in December (mean daily temperature $3.3^{\circ} \mathrm{C}$ ) and highest in July (mean daily temperature $18.0^{\circ} \mathrm{C}$ ); mean annual precipitation is $1552 \mathrm{~mm}$ with the highest precipitation in November $(249 \mathrm{~mm})$ and lowest in August (50 mm) (Table S1) [30]. The LFV has the highest number of frost-free days in all of Canada [31], with an average of 212 days per year [30].

Lower Fraser Valley soils are alluvial and highly fertile, consisting primarily of a mix of Brunisolic, Gleysolic, Organic, and Podzolic soils [32]. Soils are dominant in agricultural capability classes $1-3$. There are over 200 different soil types present in the LFV, which have been grouped into "soil agricultural management groups" [33].

The LFV generates about half of British Columbia's agriculture's farm-gate economic value, despite only containing 3\% of British Columbia's agricultural land [31]. Total arable land in the LFV is 137,750 hectares, of which 686,130 hectares are cropped [27]. Dominant crops include hay crops, pasture, field crops, fruits, berries, and vegetables, and nursery products [26]. Table 1 provides data on the total area irrigated in the LFV at 28,354 hectares, which 


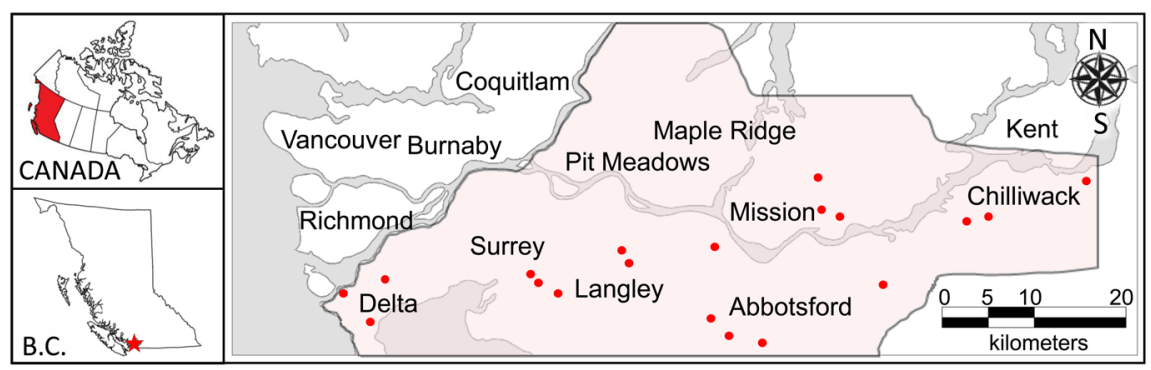

Figure 1. Location of the lower Fraser valley, British Columbia, Canada (light red) including municipalities of Chilliwack, Mission, Abbotsford, Surrey, Langley, Delta, Maple Ridge, and Pitt Meadows with locations of assessment site locations (red dots).

Table 1. Irrigation area and average annual water requirement by crop [27].

\begin{tabular}{ccc}
\hline Crop Type & Irrigation Crop Area (ha) & Average Irrigation Requirement (mm/year) \\
\hline Pasture/Grass & 178 & 562 \\
Raspberry & 1160 & 311 \\
Blueberry & 3754 & 333 \\
Vegetable & 1362 & 472 \\
Forage & 5818 & 534 \\
Strawberry & 8 & 299 \\
Sweetcorn & & 265 \\
\hline
\end{tabular}

a. Sweetcorn is corn requires 110 growing degree days after season start.

represents $41 \%$ of cropped land [27]. Currently, about $11 \%$ of the total area that is irrigated in the LFV ( $3790 \mathrm{ha}$ ) is irrigated by efficient systems such as drip, micro sprinkler, and micro spray [27].

\subsection{Site, Crop, and Irrigation Selection}

BC Government datasets ParcelMapBC [34] and the BC Soil Information Finder Tool (SIFT) [35] were used to identify parcels representing the 19 major agricultural soil management groups, as defined in the Soil Management Handbook for the Lower Fraser Valley [33] (Figure 1; Table S2). The Soil Management Handbook is a locally developed guide that groups together and describes soils in the LFV that have similar properties and agricultural management practices.

The major commercial crops for the LFV region that were selected for water demand comparisons included blueberries (Vaccinium corymbosum L.), raspberries (Rubus idaeus L.), forage (plant material used to feed livestock e.g., alfalfa, clover, corn, cereal crops), pasture (crops grown for grazing animals e.g., blends of cereal crops, ryegrass, peas, etc), corn (Zea mays L.), potato (Solanum tuberosum L.), and strawberry (Fragaria $x$ ananassa Duch.). These crops were selected as representative economically important crops for the region, and comprise a significant share of the region's agricultural output (Table 2) [26]. In addition, they are crops that may be relatively easily exchanged over a short time 
Table 2. Planting regime (e.g. annual, perennial) and estimated planted area in the LFV for selected crops [15] [36] [37].

\begin{tabular}{|c|c|c|}
\hline Crop & $\begin{array}{l}\text { Planting } \\
\text { Frequency }\end{array}$ & Estimate of Cultivated Area in the Lower Fraser Valley \\
\hline Potato & Annual & $\begin{array}{l}\text { Metro Vancouver Regional District: } 1470 \text { ha [36]. } \\
\text { Fraser Valley Regional District: } 354 \text { ha [37]. }\end{array}$ \\
\hline Corn & Annual & 8550 ha $[15]$. \\
\hline Strawberry & Biennial & $\begin{array}{l}\text { Metro Vancouver Regional District: } 170 \text { ha [36]. } \\
\text { Fraser Valley Regional District: Estimate unavailable. }\end{array}$ \\
\hline Blueberry & Perennial & $\begin{array}{l}\text { Metro Vancouver Regional District: } 5446 \text { ha [36]. } \\
\text { Fraser Valley Regional District: } 3964 \text { ha [37]. }\end{array}$ \\
\hline Raspberry & Perennial & $\begin{array}{l}\text { Metro Vancouver Regional District: } 176 \text { ha [36]. } \\
\text { Fraser Valley Regional District: } 1274 \text { ha [37]. }\end{array}$ \\
\hline Pasture & Annual & $\begin{array}{l}\text { Metro Vancouver Regional District: } 4169 \text { ha [36]. } \\
\text { Fraser Valley Regional District: } 4573 \text { ha [37]. }\end{array}$ \\
\hline Forage & Annual & $\begin{array}{l}\text { Metro Vancouver Regional District: } 8141 \text { ha [36]. } \\
\text { Fraser Valley Regional District: } 19,962 \text { ha [37]. }\end{array}$ \\
\hline
\end{tabular}

frames. While the definitions for pasture and forage are similar, this study viewed these crops separately because they could be separated inputs by the Model.

Two common types of irrigation systems, overhead sprinklers and drip irrigation, were selected for comparisons of water demand. Drip irrigation systems slowly dispense water directly over a plant's rooting zone, at the soil surface, or buried just below the soil surface. Sprinkler systems spray water through the air via a system of pumps, pipes, and sprinklers. Both systems enable a relatively uniform application of water across a field.

\subsection{Agriculture Water Demand Model}

The BC Agriculture Water Calculator v2.1.1 [38] based on the Agriculture Water Demand Model [27] was used as a comparative tool to determine the projected annual irrigation water demand for the major commercial crops on agricultural parcels in the LFV. For each soil management group, annual irrigation water demand was calculated for each crop (blueberry, raspberry, corn, forage, pasture, strawberry, potato) $\times$ irrigation system (sprinkler, drip irrigation). In some cases, a land parcel could not support a specific crop due to land capability (Scat and Ladner soil groups cannot support raspberries). Furthermore, while this study uses the Agricultural Water Demand Model to calculate both drip and sprinkler irrigation requirements, in practice drip irrigation is typically not used for pasture, forage, or corn crops.

Change in total annual irrigation water demand (TAIWD) was calculated for all possible pairings of crop $\times$ irrigation treatments. Percent change in total annual irrigation water demand (TAIWD) was calculated as: 


$$
\begin{aligned}
& \% \Delta \mathrm{TAIWD}=\left(\frac{\text { CropIrr2 AIWD }- \text { CropIrrl AIWD }}{\text { CropIrrl AIWD }}\right) * 100 \% \\
& \% \Delta \mathrm{TAIWD}=\text { percent change in total annual water demand }
\end{aligned}
$$

CropIrr1 AIWD

$=$ annual irrigation water demand for intial crop and irrigation $\operatorname{system}\left(\mathrm{m}^{3} \cdot \mathrm{ha}^{-1}\right)$

CropIrr2 Annual Irrigatoin Water Demand

$=$ annual irrigation water demand for end crop and irrigation system $\left(\mathrm{m}^{3} \cdot \mathrm{ha}^{-1}\right)$.

The Agricultural Water Demand Model is based on a Geographic Information Systems (GIS) database that integrates information about the climate, crop type, irrigation system type, soil texture at a crop's rooting depth, the soil's available water storage capacity, and peak infiltration rate to calculate agricultural water demand at various scales, from a single parcel to an entire region [39]. The information is obtained and verified through on-the-ground surveys. The Model generates polygons within a property that may be added together to determine the water demand for the property, or a watershed, groundwater region, or local government boundary. Therefore, the Model may be adapted to any geographical area for which the required data is available. A gridded climate dataset allows the water demand to be calculated daily and then summarized by month or annually.

The Agricultural Water Demand Model provides an estimate of peak irrigation flows and annual water demand for irrigation systems. Crop, irrigation system type, soils, and climate data are used to calculate the water demand. While every effort has been made to ensure the accuracy and completeness of the information, the information should be considered as a comparative best estimate. We selected the parcel ID for each of our 19 soil parcels, which auto-generated model settings for soil type (i.e. silt clay loam, clay loam, etc.), growing days, peak ET (evapotranspiration, $\mathrm{mm} /$ day), peak flow rate (refers to the flow of water from the irrigation system; gpm), and climate ID (a marker referring to a 500 by 500-metre climate grid cell in the Model that links to the climate data from the nearest weather station) (Figure 2; Table S2). We assumed that the climate conditions are similar when comparing the annual irrigation water demand among crops and irrigation systems.

For each climate grid cell, climate data incorporated into the model was used to calculate a daily reference evapotranspiration rate (Eto) using the FAO Penman-Monteith equations [27] [40]. Then, eight main steps are used to calculate the irrigation demand based on Agricultural Water Demand Model, though some crops (e.g. cranberries) require additional steps. This includes calculating pre-season moisture content, in-season precipitation, cover crop coefficient, crop evapotranspiration, climate moisture deficit, crop water requirement, irrigation requirement, and irrigation water demand [27].

A limitation of the Agricultural Water Demand Model is that the water table is not considered in the model. In the LFV, some low-lying areas have a high 


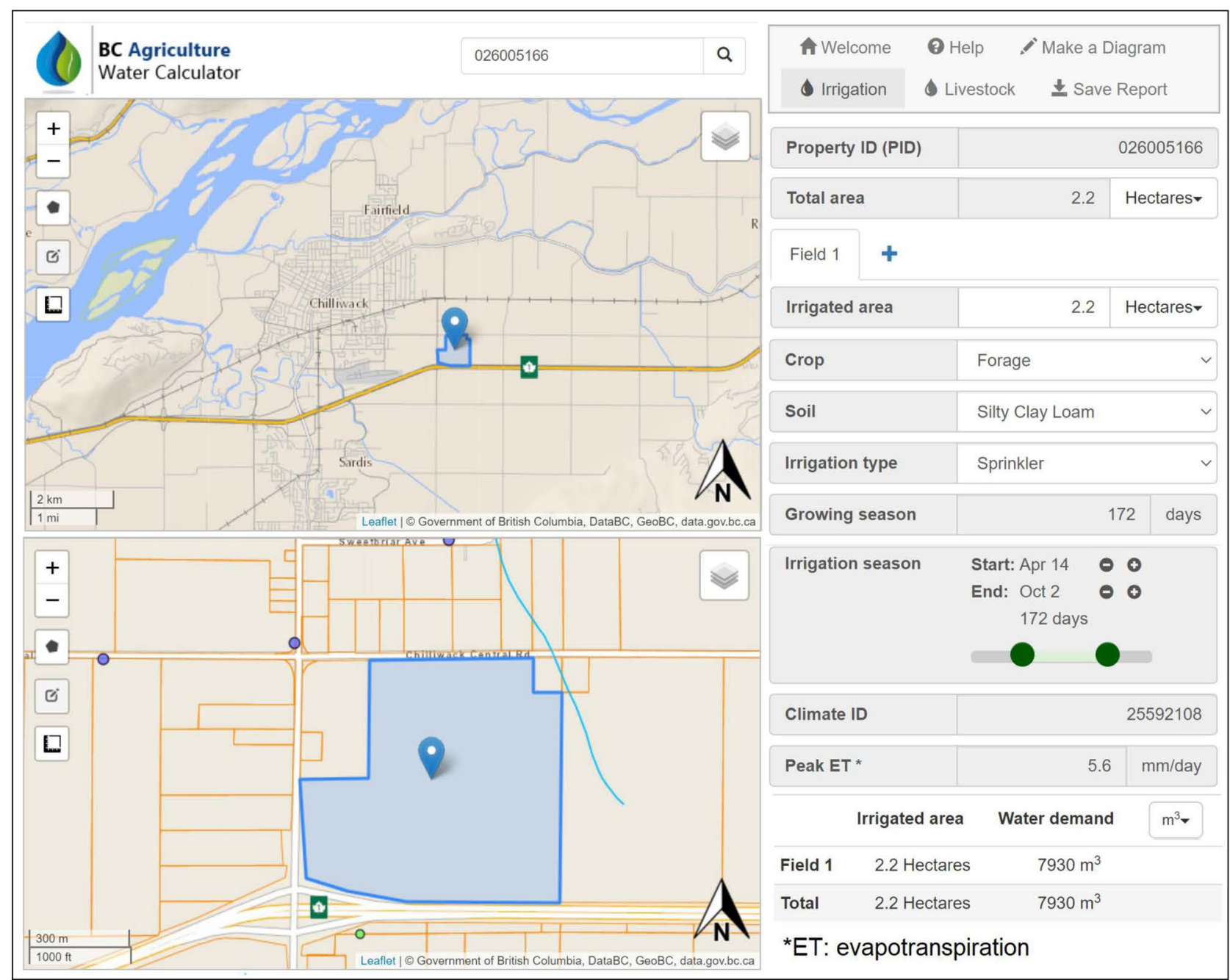

Figure 2. Example of how the agricultural water calculator is loaded. The soil parcel (in blue) was used to represent the Carvolth and Veddy soil management group [38].

water table in parts of the growing season that are within the rooting zone of commonly grown crops, thus the results from the water demand model may overestimate the real irrigation water demand for these particular areas [39].

Another limitation is that the model uses only a single soil texture class for a given parcel which may not be representative of the field as there might be several soil types/textures at a site. We selected the dominant soil texture for the area based on information gathered in the BC Soil Information Finder Tool (SIFT) [35]. In addition, soil horizons/layers may have restricted percolation rates resulting in ponding and surface runoff during intense rain events.

\section{Results}

When comparing crops using the same irrigation system, raspberry had the lowest calculated annual irrigation water demand followed by strawberry, corn, potato, blueberry; pasture and forage had the highest annual irrigation water 
demand (Table 3). There was no difference in the calculated annual irrigation water demand between forage and pasture for any of the soil types or irrigation systems. In all comparisons, the annual irrigation water demand under a drip irrigation system is relatively lower than the water demand under sprinkler irrigation. The difference in annual irrigation water demand when changing from overhead sprinkler irrigation to drip irrigation for the same crop is about $22 \%$ for all crop types. Irrigation water demand can change as much as $132 \%$ when land use (crop) or management (irrigation type) are changed (Figure 3 ). The largest reductions $(<40 \%)$ in irrigation water demand were found when switching from sprinkler-forage/pasture to drip-raspberry, -strawberry, -corn, -potato, and sprinkler-raspberry. Smaller reductions $(20 \%-40 \%)$ were found for changes from sprinkler-forage/pasture to drip-blueberry, sprinkler-blueberry, -corn, and -potato.

Annual irrigation water demand ranges from around $5000 \mathrm{~m}^{3} \cdot \mathrm{ha}^{-1}$ for forage and pasture to less than $3000 \mathrm{~m}^{3} \cdot \mathrm{ha}^{-1}$ for raspberries (Figure 4). As stated earlier, in all cases annual irrigation water demand is lower for drip irrigation than for sprinkler. When comparing crops using the same irrigation system, the lowest calculated annual irrigation water demand was found in raspberry, followed by strawberry, corn, potato, blueberry, and finally pasture and forage (which had similar total average annual irrigation water demand). Similar trends were found for selected crops grown on the different soil management groups. The annual irrigation water demand was generally higher in coarser-textured soils (Sumas, Sunshine, Bose, and Heron) compared to finer-textured and organic soils under both irrigation types, which is not unexpected.

Table 3. Total annual water irrigation demand for major crops in the Lower Fraser Valley (LFV) using sprinkler and drip irrigation. The mean total annual irrigation water demand is calculated for $\mathrm{n}=19$ soil parcels and does not consider the actual area of each crop type with the LFV. Percent difference in total annual irrigation water demand when switching from sprinkler to drip irrigation is also presented.

\begin{tabular}{cccccccc}
\hline Crop & \multicolumn{2}{c}{$\begin{array}{c}\text { Total Annual } \\
\text { Irrigation Water }\end{array}$} & \multicolumn{2}{c}{$\begin{array}{c}\text { Total Annual } \\
\text { Irrigation Water } \\
\text { Demand, Sprinkler }\left(\mathrm{m}^{3} \cdot \mathrm{ha}^{-1}\right)\end{array}$} & \multicolumn{2}{c}{$\begin{array}{c}\text { Demand, Drip }\left(\mathrm{m}^{3} \cdot \mathrm{ha}^{-1}\right) \\
\text { Difference } \\
(\%)\end{array}$} \\
\cline { 2 - 6 } & Mean & Median & SD & Mean & Median & SD & $\begin{array}{c}\text { Sprinkler } \\
\text { to Drip }\end{array}$ \\
\hline Blueberry & 2792 & 2710 & 494 & 2185 & 2120 & 386 & -21.75 \\
Forage & 3624 & 3520 & 641 & 2837 & 2760 & 502 & -21.73 \\
Corn & 2611 & 2520 & 462 & 2044 & 1980 & 361 & -21.71 \\
Pasture & 3624 & 3520 & 641 & 2834 & 2760 & 502 & -21.73 \\
Raspberry & 1995 & 1940 & 352 & 1562 & 1520 & 276 & -21.69 \\
Potato & 2686 & 2610 & 474 & 2101 & 2040 & 372 & -21.82 \\
Strawberry & 2285 & 2220 & 404 & 1789 & 1740 & 316 & -21.72 \\
\hline
\end{tabular}




\begin{tabular}{|c|c|c|c|c|c|c|c|c|c|c|c|c|c|c|c|}
\hline \multirow{3}{*}{\multicolumn{2}{|c|}{$\begin{array}{c}\text { Start } \\
\text { Irrigation + Crop }\end{array}$}} & \multicolumn{14}{|c|}{ End Irrigation + Crop } \\
\hline & & \multicolumn{7}{|c|}{ Sprinkler } & \multicolumn{7}{|c|}{ Drip } \\
\hline & & Blueberry & Raspberry & Pasture & Forage & Corn & Potato & Strawberry & Blueberry & Raspberry & Pasture & Forage & Corn & Potato & Strawberry \\
\hline \multirow{7}{*}{$\begin{array}{l}\frac{\grave{\omega}}{\text { ․ㅡㄹ }} \\
\text { के }\end{array}$} & Blueberry & & $\begin{array}{l}-28.6 \\
(0.2)\end{array}$ & $\begin{array}{l}29.8 \\
(0.1)\end{array}$ & $\begin{array}{l}29.8 \\
(0.1)\end{array}$ & $\begin{array}{l}-6.5 \\
(0.2)\end{array}$ & $\begin{array}{l}-3.8 \\
(0.4)\end{array}$ & $\begin{array}{l}-18.2 \\
(0.1)\end{array}$ & $\begin{array}{l}-21.8 \\
(0.1)\end{array}$ & $\begin{array}{l}-44.1 \\
(0.1)\end{array}$ & $\begin{array}{c}1.6 \\
(0.2)\end{array}$ & $\begin{array}{c}1.6 \\
(0.2)\end{array}$ & $\begin{array}{l}-26.8 \\
(0.1)\end{array}$ & $\begin{array}{l}-24.8 \\
(0.2)\end{array}$ & $\begin{array}{l}-35.9 \\
(0.2)\end{array}$ \\
\hline & Raspberry & $\begin{array}{l}40.0 \\
(0.2)\end{array}$ & & $\begin{array}{l}81.7 \\
(0.3)\end{array}$ & $\begin{array}{l}81.7 \\
(0.3)\end{array}$ & $\begin{array}{l}30.9 \\
(0.3)\end{array}$ & $\begin{array}{l}34.7 \\
(0.5)\end{array}$ & $\begin{array}{l}14.6 \\
(0.2)\end{array}$ & $\begin{array}{c}9.5 \\
(0.2)\end{array}$ & $\begin{array}{l}-21.7 \\
(0.1)\end{array}$ & $\begin{array}{l}42.2 \\
(0.3)\end{array}$ & $\begin{array}{l}42.2 \\
(0.3)\end{array}$ & $\begin{array}{c}2.4 \\
(0.2)\end{array}$ & $\begin{array}{c}5.3 \\
(0.2)\end{array}$ & $\begin{array}{r}-10.3 \\
(0.2)\end{array}$ \\
\hline & Pasture & $\begin{array}{r}-23.0 \\
(0.1)\end{array}$ & $\begin{array}{r}-45.0 \\
(0.1)\end{array}$ & & $\begin{array}{c}0.0 \\
(0.0)\end{array}$ & $\begin{array}{l}-28.0 \\
(0.2)\end{array}$ & $\begin{array}{l}-25.9 \\
(0.3)\end{array}$ & $\begin{array}{l}-36.9 \\
(0.1)\end{array}$ & $\begin{array}{l}-39.7 \\
(0.1)\end{array}$ & $\begin{array}{l}-56.9 \\
(0.1)\end{array}$ & $\begin{array}{l}-21.7 \\
(0.0)\end{array}$ & $\begin{array}{l}-21.7 \\
(0.0)\end{array}$ & $\begin{array}{l}-43.6 \\
(0.1)\end{array}$ & $\begin{array}{r}-42.0 \\
(0.1)\end{array}$ & $\begin{array}{l}-50.6 \\
(0.1)\end{array}$ \\
\hline & Forage & $\begin{array}{l}-23.0 \\
(0.1)\end{array}$ & $\begin{array}{l}-45.0 \\
(0.1)\end{array}$ & $\begin{array}{c}0.0 \\
(0.0)\end{array}$ & & $\begin{array}{l}-28.0 \\
(0.2)\end{array}$ & $\begin{array}{l}-25.9 \\
(0.3)\end{array}$ & $\begin{array}{l}-36.9 \\
(0.1)\end{array}$ & $\begin{array}{l}-39.7 \\
(0.1)\end{array}$ & $\begin{array}{l}-56.9 \\
(0.1)\end{array}$ & $\begin{array}{l}-21.7 \\
(0.0)\end{array}$ & $\begin{array}{l}-21.7 \\
(0.0)\end{array}$ & $\begin{array}{l}-43.6 \\
(0.1)\end{array}$ & $\begin{array}{l}-42.0 \\
(0.1)\end{array}$ & $\begin{array}{l}-50.6 \\
(0.1)\end{array}$ \\
\hline & Corn & $\begin{array}{l}7.0 \\
(0.2)\end{array}$ & $\begin{array}{l}-23.6 \\
(0.2)\end{array}$ & $\begin{array}{l}38.8 \\
(0.3)\end{array}$ & $\begin{array}{l}38.8 \\
(0.3)\end{array}$ & & $\begin{array}{c}2.9 \\
(0.4)\end{array}$ & $\begin{array}{l}-12.5 \\
(0.2)\end{array}$ & $\begin{array}{l}-16.3 \\
(0.2)\end{array}$ & $\begin{array}{l}-40.2 \\
(0.2)\end{array}$ & $\begin{array}{l}8.7 \\
(0.3)\end{array}$ & $\begin{array}{l}8.7 \\
(0.3)\end{array}$ & $\begin{array}{l}-21.7 \\
(0.0)\end{array}$ & $\begin{array}{r}-19.5 \\
(0.2)\end{array}$ & $\begin{array}{l}-31.5 \\
(0.2)\end{array}$ \\
\hline & Potato & $\begin{array}{c}3.9 \\
(0.4)\end{array}$ & $\begin{array}{l}-25.7 \\
(0.3)\end{array}$ & $\begin{array}{l}34.9 \\
(0.6)\end{array}$ & $\begin{array}{l}34.9 \\
(0.6)\end{array}$ & $\begin{array}{l}-2.8 \\
(0.4)\end{array}$ & & $\begin{array}{l}-14.9 \\
(0.2)\end{array}$ & $\begin{array}{l}-18.7 \\
(0.3)\end{array}$ & $\begin{array}{l}-41.9 \\
(0.3)\end{array}$ & $\begin{array}{l}5.6 \\
(0.4)\end{array}$ & $\begin{array}{c}5.6 \\
(0.4)\end{array}$ & $\begin{array}{l}-23.9 \\
(0.4)\end{array}$ & $\begin{array}{l}-21.8 \\
(0.0)\end{array}$ & $\begin{array}{r}-33.4 \\
(0.2)\end{array}$ \\
\hline & Strawberry & $\begin{array}{l}22.2 \\
(0.2)\end{array}$ & $\begin{array}{r}-12.7 \\
(0.1)\end{array}$ & $\begin{array}{l}58.6 \\
(0.3)\end{array}$ & $\begin{array}{l}58.6 \\
(0.3)\end{array}$ & $\begin{array}{l}14.2 \\
(0.2)\end{array}$ & $\begin{array}{l}17.6 \\
(0.4)\end{array}$ & & $\begin{array}{l}-4.4 \\
(0.2)\end{array}$ & $\begin{array}{l}-31.6 \\
(0.2)\end{array}$ & $\begin{array}{l}24.1 \\
(0.3)\end{array}$ & $\begin{array}{l}24.1 \\
(0.3)\end{array}$ & $\begin{array}{c}-10.6 \\
(0.2)\end{array}$ & $\begin{array}{l}-8.1 \\
(0.2)\end{array}$ & $\begin{array}{r}-21.7 \\
(0.1)\end{array}$ \\
\hline \multirow{7}{*}{ 음 } & Blueberry & $\begin{array}{l}27.8 \\
(0.2)\end{array}$ & $\begin{array}{l}-8.7 \\
(0.2)\end{array}$ & $\begin{array}{l}65.9 \\
(0.3)\end{array}$ & $\begin{array}{l}65.9 \\
(0.3)\end{array}$ & $\begin{array}{l}19.5 \\
(0.3)\end{array}$ & $\begin{array}{l}23.0 \\
(0.5)\end{array}$ & $\begin{array}{c}4.6 \\
(0.2)\end{array}$ & & $\begin{array}{r}-28.5 \\
(0.2)\end{array}$ & $\begin{array}{l}29.8 \\
(0.3)\end{array}$ & $\begin{array}{l}29.8 \\
(0.3)\end{array}$ & $\begin{array}{c}-6.5 \\
(0.2)\end{array}$ & $\begin{array}{l}-3.9 \\
(0.2)\end{array}$ & $\begin{array}{r}-18.1 \\
(0.2)\end{array}$ \\
\hline & Raspberry & $\begin{array}{l}78.7 \\
(0.3)\end{array}$ & $\begin{array}{l}27.7 \\
(0.2)\end{array}$ & $\begin{array}{c}132.0 \\
(0.4)\end{array}$ & $\begin{array}{c}132.0 \\
(0.4)\end{array}$ & $\begin{array}{l}67.1 \\
(0.5)\end{array}$ & $\begin{array}{l}72.0 \\
(0.8)\end{array}$ & $\begin{array}{l}46.3 \\
(0.3)\end{array}$ & $\begin{array}{l}39.9 \\
(0.3)\end{array}$ & & $\begin{array}{l}81.6 \\
(0.3)\end{array}$ & $\begin{array}{l}81.6 \\
(0.3)\end{array}$ & $\begin{array}{l}30.8 \\
(0.2)\end{array}$ & $\begin{array}{l}34.5 \\
(0.4)\end{array}$ & $\begin{array}{l}14.5 \\
(0.3)\end{array}$ \\
\hline & Pasture & $\begin{array}{l}-1.6 \\
(0.2)\end{array}$ & $\begin{array}{r}-29.7 \\
(0.1)\end{array}$ & $\begin{array}{l}27.7 \\
(0.0)\end{array}$ & $\begin{array}{l}27.7 \\
(0.0)\end{array}$ & $\begin{array}{c}-8.0 \\
(0.2)\end{array}$ & $\begin{array}{l}-5.3 \\
(0.4)\end{array}$ & $\begin{array}{r}-19.5 \\
(0.2)\end{array}$ & $\begin{array}{l}-23.0 \\
(0.2)\end{array}$ & $\begin{array}{r}-44.9 \\
(0.1)\end{array}$ & & $\begin{array}{c}0.0 \\
(0.0)\end{array}$ & $\begin{array}{c}-28.0 \\
(0.1)\end{array}$ & $\begin{array}{l}-26.0 \\
(0.2)\end{array}$ & $\begin{array}{r}-36.9 \\
(0.1)\end{array}$ \\
\hline & Forage & $\begin{array}{l}-1.6 \\
(0.2)\end{array}$ & $\begin{array}{r}-29.7 \\
(0.1)\end{array}$ & $\begin{array}{l}27.7 \\
(0.0)\end{array}$ & $\begin{array}{l}27.7 \\
(0.0)\end{array}$ & $\begin{array}{c}-8.0 \\
(0.2)\end{array}$ & $\begin{array}{l}-5.3 \\
(0.4)\end{array}$ & $\begin{array}{r}-19.5 \\
(0.2)\end{array}$ & $\begin{array}{r}-23.0 \\
(0.2)\end{array}$ & $\begin{array}{r}-44.9 \\
(0.1)\end{array}$ & $\begin{array}{c}0.0 \\
(0.0)\end{array}$ & & $\begin{array}{c}-28.0 \\
(0.1)\end{array}$ & $\begin{array}{l}-26.0 \\
(0.2)\end{array}$ & $\begin{array}{l}-36.9 \\
(0.1)\end{array}$ \\
\hline & Corn & $\begin{array}{l}36.6 \\
(0.2)\end{array}$ & $\begin{array}{c}-2.4 \\
(0.2)\end{array}$ & $\begin{array}{l}77.3 \\
(0.3)\end{array}$ & $\begin{array}{l}77.3 \\
(0.3)\end{array}$ & $\begin{array}{l}27.7 \\
(0.0)\end{array}$ & $\begin{array}{l}31.5 \\
(0.6)\end{array}$ & $\begin{array}{l}11.8 \\
(0.3)\end{array}$ & $\begin{array}{c}6.9 \\
(0.2)\end{array}$ & $\begin{array}{l}-23.6 \\
(0.1)\end{array}$ & $\begin{array}{l}38.8 \\
(0.3)\end{array}$ & $\begin{array}{l}38.8 \\
(0.3)\end{array}$ & & $\begin{array}{c}2.8 \\
(0.3)\end{array}$ & $\begin{array}{r}-12.5 \\
(0.2)\end{array}$ \\
\hline & Potato & $\begin{array}{l}32.9 \\
(0.3)\end{array}$ & $\begin{array}{l}-5.0 \\
(0.2)\end{array}$ & $\begin{array}{l}72.6 \\
(0.4)\end{array}$ & $\begin{array}{l}72.6 \\
(0.4)\end{array}$ & $\begin{array}{l}24.3 \\
(0.3)\end{array}$ & $\begin{array}{l}27.9 \\
(0.0)\end{array}$ & $\begin{array}{c}8.8 \\
(0.2)\end{array}$ & $\begin{array}{c}4.0 \\
(0.2)\end{array}$ & $\begin{array}{l}-25.6 \\
(0.2)\end{array}$ & $\begin{array}{l}35.1 \\
(0.3)\end{array}$ & $\begin{array}{l}35.1 \\
(0.3)\end{array}$ & $\begin{array}{l}-2.7 \\
(0.3)\end{array}$ & & $\begin{array}{c}-14.8 \\
(0.2)\end{array}$ \\
\hline & Strawberry & $\begin{array}{l}56.1 \\
(0.4)\end{array}$ & $\begin{array}{l}11.5 \\
(0.2)\end{array}$ & $\begin{array}{c}102.6 \\
(0.4)\end{array}$ & $\begin{array}{c}102.6 \\
(0.4)\end{array}$ & $\begin{array}{l}45.9 \\
(0.3)\end{array}$ & $\begin{array}{l}50.2 \\
(0.5)\end{array}$ & $\begin{array}{l}27.7 \\
(0.2)\end{array}$ & $\begin{array}{l}22.1 \\
(0.3)\end{array}$ & $\begin{array}{c}-12.7 \\
(0.2)\end{array}$ & $\begin{array}{l}58.6 \\
(0.4)\end{array}$ & $\begin{array}{l}58.6 \\
(0.4)\end{array}$ & $\begin{array}{l}14.2 \\
(0.3)\end{array}$ & $\begin{array}{l}17.4 \\
(0.2)\end{array}$ & \\
\hline
\end{tabular}

Figure 3. Percent change in annual irrigation water demand due to crop and irrigation system (land-use) change. The average percent change of all the soil types is shown, with the standard deviation provided in brackets. Decreases in annual irrigation water demand are shown in green, and increases are shown in red.



Figure 4. Sprinkler and drip irrigation total annual irrigation water demand $\left(\mathrm{m}^{3} \cdot \mathrm{ha}^{-1}\right)$ for all major crops and soil management groups with soil textural classes.

\section{Discussion}

\subsection{Comparative Assessment of Irrigation Water Demand for Major Crops}

The results demonstrated that significant reductions in total annual irrigation 
water demand can be made by switching irrigation systems or crops. Water requirements were consistently less for crops under drip irrigation compared to sprinkler systems. This is unsurprising as with sprinkler irrigation systems, water can be lost to the atmosphere before hitting the ground and can evaporate before being utilized by plants. Drip irrigation delivers a more targeted water supply typically applied directly on the soil surface above plant roots. This study demonstrated an average of almost $22 \%$ reduction in annual irrigation water demand from sprinkler to drip irrigation for all crop types. However, drip irrigation may not always be a viable option, and this is often the case for forage and pasture crops. In these cases, management interventions such as irrigation scheduling techniques can reduce water use [27]. Additionally, other irrigation methods which may result in decreased irrigation water demand (such as partial root drying) are not available inputs into the Agricultural Water Demand Model.

Pasture and forage crops required the highest annual irrigation water demand compared to other crops. Interestingly, despite being separate and distinct crop inputs to the model, forage, and pasture had similar water requirements. Water use by either crop will be affected by "cropping" frequency, whether by cattle (grazing intensity and rotation) or machinery or by cropping or haying multiple times during the growing season. While pasture and forage water demand had the highest annual irrigation water demand of the crops we investigated, this does not include the high water demand of the livestock production that these crops support. Van der Gulik et al. [27] estimated it takes about 45 - 65 L.day $^{-1}$ to sustain one dairy cow, and 12 and $0.1 \mathrm{~L} \cdot$ day $^{-1}$ for swine and poultry. Livestock production is very intensive in the LFV; The Census of British Columbia estimates that as of 2016 there are about 250,000 cows, over 70,000 swine and $5,500,000$ poultry in the LFV creating an additional water demand for livestock production of approximately 12.6 to $17.6 \mathrm{million} \cdot \mathrm{L} \cdot \mathrm{day}^{-1}$ [41].

In the 1990s, when many raspberry farmers started switching to blueberry crops due to economic factors including increased competition in the raspberry market and perceived profitability of blueberries, there was concern that the replacement of raspberries for highbush blueberries would increase annual irrigation water demand. This was validated in our analysis; we found that blueberries have a slightly higher annual irrigation water demand than raspberries, regardless of soil group. However, it can be difficult to precisely quantify the change in water demand with shifting land use as there is insufficient data about how many farmers are changing crops, or the change in hectares. Nevertheless, our analysis demonstrated a potential $40 \%$ increase in annual irrigation water demand for any given parcel when switching from raspberries to highbush blueberry (using the same irrigation system) in the LFV. Production of high bush blueberry in British Columbia increased 56 percent from 52,597 MT in 2012 to 82,005 MT in 2016 [42].

Potatoes and corn have relatively similar annual irrigation water demand (for sprinkler systems, an average of 2686 and $2611 \mathrm{~m}^{3} \cdot \mathrm{ha}^{-1}$ respectively). These 
crops are agronomically and socioeconomically important within the region; however, both require intensive farm practices such as high inputs of fertilizer, tillage, and water. It should be recognized that loss of organic matter may decrease soil water-holding capacity as the result of annual tillage, leading to decreased infiltration [43], which may lead to increased water demand. The negative impacts of tillage on soil organic matter content may be counteracted by planting cover crops, keeping crop residues on the soil surface, and reducing tillage as much as possible [44]. Strawberries had lower annual irrigation water demand than potato and corn at an average of $2285 \mathrm{~m}^{3} \cdot \mathrm{ha}^{-1}$ for sprinkler systems. Because strawberries do not need to be replanted every season, they are also better suited than corn and potato to drip irrigation and/or reduced tillage systems.

Soil groups with coarser textured soils (i.e. sandy loam and loamy sand) generally had higher calculated annual irrigation water demand compared to organic soils and fine-textured soils (i.e. silty clay loam, and silt loam). This is to be expected as coarse-textured soils with less organic matter tend to have lower water-holding capacity. Water demand for crop production is governed not only by crop management and its efficiency but also by the balance between atmospheric moisture deficit and soil water supply [1]. The main soil factors influencing soil water holding capacity are soil texture (influences pore space) and organic matter content (influences formation of soil aggregates); texture cannot be managed but organic matter can. In cases where more efficient irrigation systems are not a possibility, organic matter additions to the soil (i.e. by applications of manure or compost) can help to improve soil water holding capacity, leading to reduced irrigation water demand over time [45] [46] [47]. Organic matter additions can also help moderate soil temperatures and increase nutrient and exchange [48]. For example, sawdust mulch is often used for weed suppression in blueberries, but this practice also provides water management benefits [49]. By providing a physical barrier between the soil and atmosphere, sawdust mulch reduces evaporative water loss and moderates soil temperature [50] [51] [52].

\subsection{Application of the Agricultural Water Demand Model for Water Scarcity}

Water demand is only one consideration for crop selection. Inevitably, economics and social factors have a large role to play when farmers are selecting their crops. For example, in the LFV, insecure land tenures do not incentivize farmers to invest in improving soil conservation practices on their farms [52]. In addition, with the recent introduction of the Water Sustainability Act in British Columbia, it is expected that water prices will increase [53]. As a result, the irrigation water demand of a given crop may become an increasingly important consideration for the profitability of farming, as farmers are highly adaptable to changes in market conditions and access to productive inputs, including water [5].

For the crop types and irrigation systems included in this study, changing the 
land use and/or irrigation system could result in increases in annual irrigation water demand of up to $132 \%$. However, a change to a more water-efficient crop or irrigation system could result in reductions of annual irrigation water demand of up to $57 \%$. As climate change and human water withdrawals continue to pressure the water resource base in the LFV, the impacts of inefficient use of irrigation water will only increase. In British Columbia, potential increases in irrigation water demand in response to climate change have been estimated to range from $21 \%$ to $58 \%$, to as high as $30 \%$ to $114 \%$ depending on climate change estimates [10]. Furthermore, agricultural land development scenarios could result in significant potential increases in regional irrigation water demand, up to $2400 \%$ [10]. A change of land use or irrigation system on a singular parcel may not have a large impact on regional water dynamics, but at a large scale shifting land use can greatly affect regional water demand and water availability.

\subsection{Strategies to Manage Water Demand-Water Use Efficiency and the Cropping System}

It is estimated that all total available water will be allocated in the LFV within the next 15 - 20 years [27]. This concern for water resource vulnerability is further compounded by predicted climate change, which will increase the challenges faced with water scarcity and food security [54]. In British Columbia, climate change is expected to cause a decrease in winter snowfall and summer precipitation, and an increase in temperature, meaning that more water will be required for crop and livestock production [13]. These changes in precipitation patterns can lead to more frequent and severe droughts, which are already a concern. In 2015, conditions in British Columbia were extremely dry and there was insufficient water to meet community, agricultural, and ecosystem needs [55]. This caused severe socio-economic impacts and resulted in temporary water use restrictions for municipal, industrial, and agricultural uses [55].

Compounding the challenge of water supply is the concern for food security, as less than 5\% of BC's total land is suitable for agriculture [26]. In addition, because the highly productive land in the LFV is also desirable for urban development, urban areas and agriculture co-exist in lowland areas, leading to increased competition for water [10].

\section{Conclusions}

The Agricultural Water Demand Model is a scientifically-based, useful, comparative tool to assess irrigation demand among locally grown crops based on relevant and readily available information about climate, crop needs, and soil parameters. The Agricultural Water Demand Model can aid in decision-making for the effective management of local water resources. This study demonstrated that irrigation water demand can be effectively reduced by changing from sprinkler to drip irrigation and that irrigation water demand can be reduced by choosing crops that are more water-efficient or can be irrigated by surface water sources 
rather than groundwater sources. Coarse-textured soils have higher water demand than finer textured soils, but strategic decisions that consider the crop's suitability, tillage requirements, and organic matter additions, like sawdust mulch, can effectively reduce evapotranspiration of soil water of row crops.

To extend the results of this study, there is a need to explore the dynamic economic and social forces influencing crop choice and land-use dynamics over time. There is also a need for researchers to collaborate with local authorities to share data about land-use trends and quantify changes in irrigation water demand to better understand how shifting land-use dynamics and irrigation technologies may be impacting local hydrology and the availability of water. The information presented in this study may be used by farmers as an input into their economic analysis of their operations, as well as government agencies in evaluating water policy. The Agricultural Water Demand Model is flexible and only requires local information which is often rather easily obtained and thus, the model could be adapted and applied to other agricultural regions globally that experience similar concerns of water scarcity.

\section{Conflicts of Interest}

The authors declare no conflicts of interest regarding the publication of this paper.

\section{References}

[1] IPCC (2014) Summary for Policymakers. In: Field, C.B., Barros, V.R., Dokken, D.J., Mach, K.J., Mastrandrea, M.D., Bilir, T.E., Chatterjee, M., Ebi, K.L., Estrada, Y.O., Genova, R.C., Girma, B., Kissel, E.S., Levy, A.N., MacCracken, S., Mastrandrea, P.R. and White, L.L., Eds., Climate Change 2014: Impacts, Adaptation, and Vulnerability. Part A: Global and Sectoral Aspects. Contribution of Working Group II to the Fifth Assessment Report of the Intergovernmental Panel on Climate Change, Cambridge University Press, Cambridge, 32 p.

[2] Boretti, A. and Rosa, L. (2019) Reassessing the Projections of the World Water Development Report. NPJ Clean Water, 2, Article No. 15.

[3] Pfister, S., Bayer, P., Koehler, A. and Hellweg, S. (2011) Projected Water Consumption in Future Global Agriculture: Scenarios and Related Impacts. The Science of the Total Environment, 409, 4206-4216.

https://doi.org/10.1016/j.scitotenv.2011.07.019

[4] Food and Agriculture Organization of the United Nations (FAO) (2017) Water for Sustainable Food and Agriculture-A Report Produced for the G20 Presidency of Germany. http://www.fao.org/3/i7959e/i7959e.pdf

[5] Food and Agriculture Organization of the United Nations (FAO) (2012) Coping with Water Scarcity: An Action Framework for Agriculture and Food Scarcity. FAO Water Reports, 38. 79 p. http://www.fao.org/3/i3015e/i3015e.pdf

[6] Statistics Canada (2010) Human Activity and the Environment: Freshwater Supply and Demand in Canada. Section 2, Catalogue No. 16-201-X. https://tinyurl.com/w974tt3h

[7] Molden, D. (2007) Water for Food, Water for Life: A Comprehensive Assessment of 
Water Management in Agriculture. Earthscan, and Columbo: International Water Management Institute, London, $40 \mathrm{p}$.

[8] Hall, K. and Schreier, H. (1996) Urbanization and Agricultural Intensification in the Lower Fraser River Valley: Impacts on Water Use and Quality. GeoJournal, 40, 135-146.

[9] Döll, P., Hoffmann-Dobrev, H., Portmann, F.T., Siebert, S., Eicker, A., Rodell, M., Strassberg, G. and Scanlon, B.R. (2012) Impact of Water Withdrawals from Groundwater and Surface Water on Continental Water Storage Variations. Journal of Geodynamics, 59-60, 143-156.

[10] Neilsen, D., Bakker, M., Van der Gulik, T., Smith, S., Cannon, A., Losso, I. and Warwick Sears. A. (2018) Landscape Based Agricultural Water Demand Modeling-A Tool for Water Management Decision Making in British Columbia, Canada. Frontiers in Environmental Science, 6, Article No. 74. https://doi.org/10.3389/fenvs.2018.00074

[11] Middleton, M.A. and Allen, D.M. (2017) Assessment of Hydraulic Connectivity Related to Groundwater Extraction on Selected Streams: Stream Vulnerability Mapping. Water Science Series, Victoria.

[12] Naugler, T.L. (2007) Groundwater-Surface Water Interactions in the Salmon River Watershed, BC: Integrating Spectroscopy, Isotopes, Water Quality, and Land Use Analyses. MSc Thesis, University of British Columbia, Vancouver, 175 p. https://tinyurl.com/7f3sppd6

[13] Shrestha, R.R., Berland, A.J., Schnorbus, M.A. and Werner, A.T. (2011) Climate Change Impacts on Hydroclimactic regimes in the Peace and Columbia Watersheds, British Columbia, Canada. Pacific Climate Impacts Consortium, University of Victoria, Victoria, $37 \mathrm{p}$.

[14] Gower, T. and Barroso, A. (2019) Tapped Out: A Special Report on Water Scarcity and Water Solutions in British Columbia. Prepared for Watershed Watch Salmon Society, Coquitlam, $24 \mathrm{p}$.

[15] Gasser, P., Smith, C.A.S., Brierley, J.A., Schut, P.H., Neilsen, D. and Kenney, E.A. (2016) The Use of the Land Suitability Rating System to Assess Climate Change Impacts on Corn Production in the Lower Fraser Valley of British Columbia. Canadian Journal of Soil Science, 96, 256-269. https://doi.org/10.1139/cjss-2015-0108

[16] Van der Gulik, T., Neilsen, P.D., Fretwell, R. and Tam, S. (2016) Agricultural Water Demand Model. Okanagan Basin Report, 45 p. https://tinyurl.com/4sv3dvke

[17] Van der Gulik, T., Neilsen, P.D. and Fretwell, R. (2010) Agricultural Water Demand Model. Report for Okanagan Basin. 60 p. https://tinyurl.com/rkzj64r6

[18] Tam, S. and Van der Gulik, T. (2020) Agricultural Water Demand Model. Report for Sunshine Coast Regional District. https://tinyurl.com/4njkuzj4

[19] Tam, S. and Van der Gulik, T. (2020) Agricultural Water Demand Model. Report for Qathet Regional District. https://tinyurl.com/jh4fy2zd

[20] Tam, S. and Van der Gulik, T. (2019) Agricultural Water Demand Model. Report for Capital Regional District. https://tinyurl.com/7e7c9842

[21] Tam, S. and Van der Gulik, T. (2017) Agricultural water demand model. Report for Salt Spring Island. https://tinyurl.com/ye9jt8rb

[22] BC Ministry of Agriculture and Lands (2015) Agricultural Water Demand Model. https://waterbucket.ca/cfa/files/2015/09/Agriculture-Water-Demand-Model_2015.pdf

[23] Srinivasan, R., Arnold, J.G. and Jones, C.A. (1998) Hydrologic Modeling of the United States with the Soil and Water Assessment Tool. International Journal of 
Water Resources Development, 14, 315-325.

[24] Williams, J.R. and Izaurralde, R.C. (2006) The APEX Model. In: Singh, V.P. and Frevert, D.K., Eds., Watershed Models, CRC Press, Boca Raton, 437-482.

[25] Babbar-Sebens, M., Mukhopadhyay, S., Singh, V.B. and Piemonti, A.D. (2015) A Web-Based Software Tool for Participatory Optimization of Conservation Practices in Watersheds. Environmental Modelling \& Software: With Environment Data News, 69, 111-127. https://doi.org/10.1016/j.envsoft.2015.03.011

[26] Fraser Valley Regional District (FVRD) (2017) Regional Snapshot Series: Agricultural Economy in the Fraser Valley Regional District. Regional Snapshot Series: Agriculture, Chilliwack, $20 \mathrm{p}$. https://tinyurl.com/93mdwsyt

[27] Van der Gulik, T., Tam, S., Neilsen, P.D. and Fretwell, R. (2015) Agricultural Water Demand Model. Report for Fraser Valley Regional District, 54 p. https://tinyurl.com/ppxmfm5p

[28] Statistics Canada (2016) Over a Quarter of Gross Farm Receipts from Greenhouse and Nursery Production in British Columbia. https://tinyurl.com/3s69yj6m

[29] BC Ministry of Agriculture and Lands (2010) Market Analysis Report: Identifying Opportunities for British Columbia's Highbush Blueberry Industry. https://tinyurl.com/5f6ju4h9

[30] Environment Canada (2021) Canadian Climate Normals 1981-2010 Station Data: Abbotsford, Chilliwack, Delta, Maple Ridge, Mission, and Surrey BC. https://climate.weather.gc.ca/climate_normals/index_e.html

[31] Stobbe, T., Eagle, A.J. and van Kooten, G.C. (2010) Niche and Direct Marketing in the Rural-Urban Fringe: A Study of the Agricultural Economy in the Lower Mainland and Fraser Valley. BC Studies, 167, 105-134.

[32] Canadian Society of Soil Science (CSSS) (2020) Soils of Canada. https://soilsofcanada.ca/

[33] Bertrand, R.A., Hughes-Games, G.A. and Nikkel, T.C. (1991) Soil Management Handbook for the Lower Fraser Valley. BC Ministry of Agriculture and Food. https://tinyurl.com/4akunsb6

[34] Government of British Columbia (2016) ParcelMap BC Parcel Polygons. Data Catalogue. https://cat.data.gov.bc.ca/dataset/parcelmap-bc-parcel-polygons

[35] Government of British Columbia (n.d.) B.C. Soil Information Finder Tool. https://tinyurl.com/2pa52eyw

[36] BC Ministry of Agriculture (2014) Agricultural Land Use Inventory: Metro Vancouver Regional District, Summer 2010 \& 2011.

[37] BC Ministry of Agriculture (2016) Agricultural Land Use Inventory: Fraser Valley Regional District, Summer 2011-2013.

[38] Government of British Columbia (2021) B.C. Agriculture Water Calculator (v2.1.1.). https://bcwatercalculator.ca/agriculture/welcome

[39] Van der Gulik, T. (2015) The Fraser River, Agriculture, Food Security, and the Impacts of a Changing Climate. Presentation. BC Ministry of Agriculture, Victoria BC.

[40] Doorenbos, J. and Pruitt, W.O. (1977) Guidelines for Predicting Crop Water Requirements. FAO Irrigation and Drainage Paper. Food and Agriculture Organization of the United Nations, Rome, $145 \mathrm{p}$. http://www.fao.org/3/f2430e/f2430e.pdf

[41] BC Ministry of Agriculture (2020). Agriculture in Brief, British Columbia 2016. 
https://www2.gov.bc.ca/assets/gov/farming-natural-resources-and-industry/agricult ure-and-seafood/statistics/census/census-2016/aginbrief_2016_all_province_region _regional_districts.pdf

[42] Watters, A. (2018) High Bush Blueberry Production in Canada. USDA Foreign Agricultural Service-Global Agricultural Information Network.

https://www.fas.usda.gov/data/canada-high-bush-blueberry-production-canada

[43] Reicosky, D.C., Kemper, W.D., Langdale, G.W., Douglas, C.L.J. and Rasmussen, P.E. (1995) Soil Organic Matter Changes Resulting from Tillage and Biomass Production. Journal of Soil and Water Conservation, 50, 253.

https://ezproxy.library.ubc.ca/login?url=https://www-proquest-com.ezproxy.library. ubc.ca/scholarly-journals/soil-organic-matter-changes-resulting-tillage/docview/22 0973441/se-2?accountid $=14656$

[44] Al-Kaisi, M.M. and Lowery, B. (2017) Soil Health and Intensification of Agroecosystems. Academic Press, Cambridge.

[45] Rayne, N. and Aula, L. (2020) Livestock Manure and the Impacts on Soil Health: A Review. Soil Systems, 4, Article No. 64. https://doi.org/10.3390/soilsystems4040064

[46] Libohova, Z., Seybold, C., Wysocki, D., Wills, S., Schoeneberger, P., Williams, C. Lindbo, D., Stott, D. and Owens, P.R. (2018) Reevaluating the Effects of Soil Organic Matter and Other Properties on Available Water-Holding Capacity Using the $\mathrm{Na}$ tional Cooperative Soil Survey Characterization Database. Journal of Soil and Water Conservation, 73, 411-421. https://doi.org/10.2489/jswc.73.4.411

[47] Kowaljow, E., Gonzalez-Polo, M. and Mazzarino, M.J. (2017) Understanding Compost Effects on Water Availability in a Degraded Sandy Soil of Patagonia. Environmental Earth Sciences, 76, Article No. 255.

[48] Food and Agriculture Organization of the United Nations (FAO) (2005) The Importance of Soil Organic Matter. Food and Agriculture Organization of the United Nations, Rome.

[49] Hunt, J. F., Honeycutt, C. W. and Yarborough, D. (2010) Effect of Pine Bark Mulch on Lowbush Blueberry (Vaccinium angustifolium) Water Demand. International Journal of Fruit Science, 10, 390-415. https://doi.org/10.1080/15538362.2010.530117

[50] Chen, S.Y., Zhang, X.Y., Pei, D., Sun, H.Y. and Chen, S.L. (2007) Effects of Straw Mulching on Soil Temperature, Evaporation and Yield of Winter Wheat: Field Experiments on the North China Plain. Annals of Biology, 150, 261-268.

[51] Monks, C.D., Monks, D.W., Basden, T., Selders, A., Poland, S. and Rayburn, E. (1997) Soil Temperature, Soil Moisture, Weed Control, and Tomato (Lycopersieon esculentum) Response to Mulching. Weed Technology, 11, 561-566.

[52] Fraser, E.D.G. (2004) Land Tenure and Agricultural Management: Soil Conservation on Rented and Owned Fields in Southwest British Columbia. Agriculture and Human Values, 21, 73-79. https://doi.org/10.1023/B:AHUM.0000014020.96820.a1

[53] (2014) Canada Water Sustainability Act 2014 (BC). https://www.bclaws.gov.bc.ca/civix/document/id/complete/statreg/14015

[54] Misra, A.K. (2014) Climate Change and Challenges of Water and Food Security. International Journal of Sustainable Built Environment, 3, 153-165. https://doi.org/10.1016/j.ijsbe.2014.04.006

[55] Government of British Columbia (2015) South Coast/Lower Fraser Drought Level Increased. https://news.gov.bc.ca/releases/2015FLNR0189-00112 


\section{Supplemental Materials}

Table S1. Climate normal data (1980-2010) for the Lower Fraser Valley (data compiled from Abbotsford, Chilliwack, Delta, Maple Ridge, Mission, and Surrey climate stations. Data obtained from Environment Canada [30].

\begin{tabular}{|c|c|c|c|c|c|c|c|c|c|c|}
\hline \multirow{2}{*}{ Month } & \multirow{2}{*}{$\begin{array}{c}\text { Daily Average } \\
\text { Temp. }\left({ }^{\circ} \mathrm{C}\right)\end{array}$} & \multirow{2}{*}{$\begin{array}{l}\text { Daily Max. } \\
\text { Temp. }\left({ }^{\circ} \mathrm{C}\right)\end{array}$} & \multirow{2}{*}{$\begin{array}{l}\text { Daily Min. } \\
\text { Temp. }\left({ }^{\circ} \mathrm{C}\right)\end{array}$} & \multirow{2}{*}{$\begin{array}{c}\text { Rainfall } \\
(\mathrm{mm})\end{array}$} & \multirow{2}{*}{$\begin{array}{l}\text { Snowfall } \\
(\mathrm{cm})\end{array}$} & \multirow{2}{*}{$\begin{array}{l}\text { Precipitation } \\
\quad(\mathrm{mm})\end{array}$} & \multicolumn{4}{|c|}{ Days with Precipitation } \\
\hline & & & & & & & $>0.2 \mathrm{~mm}$ & $>5 \mathrm{~mm}$ & $>10 \mathrm{~mm}$ & $>25 \mathrm{~mm}$ \\
\hline January & 3.6 & 6.2 & 0.9 & 196.6 & 19.4 & 215.9 & 20.0 & 12.3 & 7.6 & 2.2 \\
\hline February & 4.9 & 8.4 & 1.4 & 119.7 & 8.6 & 128.3 & 15.6 & 8.0 & 4.4 & 0.8 \\
\hline March & 7.2 & 11.2 & 3.2 & 135.8 & 5.4 & 141.2 & 18.5 & 9.2 & 5.1 & 0.9 \\
\hline April & 10.0 & 14.5 & 5.4 & 117.3 & 0.6 & 117.9 & 16.6 & 7.8 & 4.1 & 0.7 \\
\hline May & 13.1 & 17.8 & 8.2 & 99.2 & 0.0 & 99.2 & 14.7 & 6.4 & 3.5 & 0.6 \\
\hline June & 15.7 & 20.4 & 10.9 & 79.8 & 0.0 & 79.8 & 12.9 & 5.3 & 2.7 & 0.4 \\
\hline July & 18.0 & 23.3 & 12.7 & 50.2 & 0.0 & 50.2 & 8.1 & 3.1 & 1.6 & 0.3 \\
\hline August & 18.2 & 23.6 & 12.7 & 49.9 & 0.0 & 49.9 & 7.5 & 3.0 & 1.6 & 0.4 \\
\hline September & 15.4 & 20.6 & 10.1 & 70.3 & 0.0 & 70.3 & 9.0 & 4.2 & 2.4 & 0.6 \\
\hline October & 10.6 & 14.3 & 6.8 & 158.2 & 0.2 & 158.3 & 16.3 & 8.7 & 5.6 & 1.5 \\
\hline November & 6.1 & 8.8 & 3.4 & 243.7 & 6.2 & 249.8 & 20.9 & 13.3 & 8.9 & 2.5 \\
\hline December & 3.3 & 5.8 & 0.8 & 175.4 & 16.8 & 192.1 & 19.5 & 11.4 & 7.1 & 1.9 \\
\hline Annual & 10.5 & 14.6 & 6.4 & 1495.7 & 57.2 & 1552.9 & 179.5 & 92.5 & 54.2 & 12.7 \\
\hline
\end{tabular}

Table S2. Soil parcel information and BC agriculture water calculator outputs. Listed property IDs will generate outputs for irrigated area (ha), soil (texture), growing season (days) irrigation season (days), climate ID, and peak evapotranspiration (mm/day).

\begin{tabular}{|c|c|c|c|c|c|c|c|}
\hline Site & Property ID & $\begin{array}{c}\text { Soil Management } \\
\text { Group }\end{array}$ & Soil Type & $\begin{array}{l}\text { Soil Texture at } \\
\text { Rooting Depth }\end{array}$ & $\begin{array}{l}\text { Growing } \\
\text { Season }\end{array}$ & $\begin{array}{l}\text { Irrigation } \\
\text { Season }\end{array}$ & Climate ID \\
\hline 1 & 026005166 & Carvolth, Veddy & Pelly & Silty clay loam & 172 days & April 14-Oct. 2 & 25592108 \\
\hline 2 & 013325761 & Whatcom & Whatcom & Silt loam & 146 days & April 13-Sept. 5 & 25702034 \\
\hline 3 & 013380192 & Abbotsford, Ryder & Abbotsford & Silt loam & 171 days & April 15-Oct. 2 & 25942048 \\
\hline 4 & 008586632 & Monroe & Lickman & Silt loam & 172 days & April 14-Oct 2 & 25932048 \\
\hline 5 & 029308615 & Fairfield & Fairfield & Silty clay loam & 171 days & April 15-Oct 2 & 25602063 \\
\hline 6 & 006551556 & Page, Pitt, Prest & Page & Silty clay loam & 172 days & April 14-Oct 2 & 25622068 \\
\hline 7 & 010812881 & Alouette, Blundell & Annis & Silt loam & 169 days & April 14-Oct 2 & 25532061 \\
\hline 8 & 009342486 & Scat & Scat & Silt loam & 168 days & April 18-Oct 2 & 25882034 \\
\hline 9 & 025086073 & Columbia, Sunshine & Columbia & Loamy sand & 171 days & April 15-Oct 2 & 25086073 \\
\hline 10 & 030039363 & $\begin{array}{c}\text { Bose, Buntzen, Capilano, } \\
\text { Coghlan, Harrison, Sardis, Salish }\end{array}$ & Cheam & Sandy loam & 168 days & April 18-Oct 2 & 25492134 \\
\hline 11 & 002405342 & Sumas & Sumas & Loamy sand & 173 days & April 13-Oct 2 & 25782081 \\
\hline 12 & 006469480 & Cloverdale & Cloverdale & Silt clay loam & 171 days & April 15-Oct 2 & 25762011 \\
\hline 13 & 007843542 & Delta & Nicomekl & Silty loam & 174 days & April 12-Oct 2 & 25821987 \\
\hline 14 & 012049441 & Berry & Berry & Silty clay loam & 171 days & April 15-Oct 2 & 25732009 \\
\hline 15 & 012011479 & Vinod & Vinod & Organic & 174 days & April 12-Oct 2 & 25801984 \\
\hline
\end{tabular}


S. Kylstra et al.

\section{Continued}

\begin{tabular}{cccccccc}
\hline 16 & 011131829 & Ladner & Ladner & Silty loam & 176 days & April 10-Oct 2 & 25831945 \\
17 & 002392135 & Benson, Guichon, Spetifore & Guichon & Silty clay loam & 176 days & April 10-Oct 2 & 25931942 \\
18 & 002503930 & Heron, Murrayville, Summer & Heron & Sandy loam & 174 days & April 12-Oct 2 & 25841992 \\
19 & 002297116 & Crescent & Crescent & Silt loam & 176 days & April 10-Oct 2 & 25871934 \\
\hline
\end{tabular}

